https://doi.org/10.19195/0137-1150.173.43

Data przesłania artykułu: 5.09.2019

Data akceptacji artykułu: 5.02.2020

MAGDALENA ŚLAWSKA

Uniwersytet Wrocławski, Polska

\title{
Archiwizacja i muzealizacja pamięci pokoleniowej. Jasminko Halilović Djetinjstvo u ratu. Sarajevo 1992-1995. oraz Muzej ratnog djetinjstva
}

\begin{abstract}
Djetinjstvo u ratu za mene je najteža i najljepša stvar u životu, i sada znam da sam upravo tad postala bolji čovjek...
\end{abstract}

Maja, $1978^{1}$

Często mówi się, że Sarajewo to miasto, w którym symbolicznie rozpoczął się i zakończył wiek XX. Stolicę Bośni i Hercegowiny — jej wygląd oraz tożsamość - w szczególny sposób ukształtował konflikt z lat dziewięćdziesiątych minionego stulecia oraz oblężenie trwające 1425 dni. Wydarzenia te są swego rodzaju punktem zwrotnym, determinując też sposób określania czasu. Ich uczestnicy podkreślają, że: „Vrijeme se u Sarajevu [...] dijeli na prije, u toku i poslije rata" [s. 15]. Współczesne Sarajewo to przede wszystkim ludzie, którzy przetrwali koszmar wojny i do dziś skazani są na bolesne wspomnienia. W niniejszym szkicu uwagę pragnę skierować na doświadczenia najmłodszych mieszkańców miasta. Szacuje się, że podczas oblężenia mieszkało w nim ponad 70 tysięcy dzie$\mathrm{ci}^{2}$. Po piętnastu latach od zakończenia konfliktu stały się one adresatami dwóch projektów dążących do archiwizacji oraz muzealizacji czy umuzealnienia pamięci zbiorowej. Pierwszy z nich to zbiór wspomnień zatytułowany Djetinjstvo u ratu. Sarajevo 1992-1995., który drukiem ukazał się w 2012 roku, drugi zaś to powo-

1 J. Halilović, Djetinjstvo u ratu. Sarajevo 1992-1995., Sarajevo 2012, s. 105. Wszystkie cytaty pochodzą z tego wydania. Stronę podaję w tekście zasadniczym.

2 Zob. ibidem, s. 25. 
łane do życia pięć lat później Muzeum Wojennego Dzieciństwa (Muzej ratnog djetinjstva). Inicjatorem obydwu przedsięwzięć jest sarajewski pisarz i aktywista Jasminko Halilović, który podobnie jak tysiące rówieśników wczesne lata życia spędził w ogarniętym wojną mieście, o czym wspomina w słowach:

Rođen sam u Sarajevu 1988. Sve što znam o preratnom vremenu je iz priča ili sa fotografija. Na njima moje djetinjstvo izgleda bezbrižno. [...] Moje „u toku rata” je u meni. Ponešto od toga dijelio sam s drugima, nekih stvari se sjećam jasno, a neke povežem tek nakon što čujem nešto o tome. [...] Negdje sam pročitao da djeca počinju jasnije pamtiti od četvrte godine. Moja četvrta godina je bila i prva godnina rata. [s. 15, 16]

Jasminko Halilović w 2010 roku opublikował w internecie otwarte zaproszenie skierowane do wszystkich, którzy lata dzieciństwa spędzili w oblężonym Sarajewie, aby krótko, w jednym lub dwóch zdaniach, odpowiedzieli na pytanie, czym jest dla nich dzieciństwo w czasie wojny. O początkach tego projektu jego pomysłodawca pisze:

Više puta sam počinjao pisati, ali nakon odličnih individualnih dnevnika koji su već objavljeni bilo je gotovo nemoguće da pojedinac ponudi nešto novo. Razgovarajući s ljudima ustanovio sam da je svako u sebi čuvao ponešto jedinstveno. Tada sam odlučio: knjigu ću otvoriti za sve nas. [...] Poziv sam usmjerio na Sarajevo iz praktičnih razloga: znao sam da su naši kapaciteti za širenje ideje ograničenji, i da ću u svakom slučaju dobiti uvjerljivo najveći broj sjećanja iz Sarajeva. Taj uzorak ne bi bio reprezentativan za cijelu BiH, i stoga sam iako vjerujem da je iskustvo djece u svim gradovima i svim ratovima slično — poziv usmjerio na ljude odrasle u Sarajevu. [s. 25]

Idea stworzenia zbioru zawierającego przemyślenia dotyczące doświadczenia zbiorowego całego pokolenia sarajewian została rozpropagowana głównie w mediach społecznościowych i spotkała się z ogromnym zainteresowaniem. Bardzo szybko zaczęły spływać wspomnienia ludzi rozsianych po całym świecie $^{3}$. W krótkim czasie uzbierało się ich przeszło 1500. Po dwóch latach prac redakcyjnych ukazała się książka, w której zebrano 1030 wpisów, tym samym — jak podkreśla autor — „obuhvaćen je reprezentativan uzorak — u knjizi je sjećanje iz svakog dijela grada, iz gotovo svake gradske ulice" [s. 25]. Chociaż projekt skierowany był przede wszystkim do mieszkańców wojennego Sarajewa, w zbiorze znalazły się również wspomnienia osób z innych miast ${ }^{4}$. Najmłodsi uczestnicy projektu przyszli na świat w 1992 roku, a więc w momencie wybuchu wojny w Bośni i Hercegowinie, najstarsi zaś urodzili się w roku 19745. Krótka forma wpisu, ograniczona jedynie do 160 znaków, a więc do długości jednej wia-

${ }^{3}$ Osoby, które tuż po wojnie lub jeszcze w trakcie jej trwania wyjechały z Sarajewa i obecnie mieszkają w USA, Niemczech, Austrii, Norwegii, Szwecji, Danii, Japonii, Kambodży czy Hongkongu, nadesłały 20\% wszystkich wpisów. Zob. ibidem, s. 27.

${ }^{4}$ Swoje wspomnienia nadesłali między innymi mieszkańcy Goraždže, Bosanskiego Brodu, Tuzli, Zenicy, Mostaru czy Banjaluki. Zob. ibidem.

${ }^{5}$ Najwięcej zamieszczonych w zbiorze wpisów to wspomnienia osób urodzonych między rokiem 1977 i 1988. Łącznie jest ich 874 - 84,9\% całości. Blisko 10\% zapisów zredagowały osoby z rocznika 1984, które w chwili wybuchu wojny liczyły zaledwie osiem lat. 
domości SMS, wymogła na uczestnikach ujawnienie wspomnień, które najmocniej zapisały się w pamięci.

Zbiór Djetinjstvo u ratu podzielony został na trzy części. W pierwszej, mającej charakter wprowadzenia, czytelnik odnajdzie informacje na temat Bośni i Hercegowiny, Sarajewa, oblężenia miasta oraz krótką opowieść o wojennych losach autora. Drugą część tworzą nadesłane wpisy. Natomiast w trzeciej zgromadzone zostały dłuższe zapiski. Są to najczęściej wiersze oraz fragmenty dzienników i listów, bogato ilustrowane fotografiami przedstawiającymi głównie rękopisy przytaczanych tekstów. Pomysł stworzenia trzeciej części zbioru narodził się podczas gromadzenia materiału, kiedy to okazało się, że wiele osób nie potrafi ograniczyć ram pamięci jedynie do stu sześćdziesięciu znaków oraz że wojenną zawieruchę przetrwało bardzo wiele zapisków prowadzonych na bieżąco podczas jej trwania.

Razgovor z ljudima koji su se odazvali pozivu pomogao mi je da shvatim složenost iskustva odrastanja u ratu. Sa stotinama njih razmjenjivao sam e-mailove. Neki su slali više desetina stranica svojih sjećanja ili dnevničkih zapisa. U mnogim od njih sakrivene su cijele knjige. Trudio sam se otvoriti im prostor koliko sam mogao. [...] u jednom dijelu knjige dati ljudima više prostora da ispričaju ono što čuvaju u sebi. Tako je nastao treći dio knjige. [s. 29, 31]

Relacje zebrane w obydwu częściach nie są anonimowe, pod każdą z nich pojawia się imię oraz rok urodzenia autora. Ze względu na charakter rozważań w dalszej części wywodu ograniczę się jedynie do wspomnień zawartych w drugiej części zbioru, odwołując się między innymi do ustaleń teoretycznych, które poczynił Paul Ricoeur w zbiorze Pamięć, historia, zapomnienie, oraz badań nad postpamięcią, w szczególności do prac autorstwa Marianne Hirsch.

Wpisy nadesłane przez uczestników projektu zajmują łącznie 189 stron książki. $\mathrm{Na}$ każdej stronie zamieszczonych zostało od pięciu do siedmiu wspomnień. Niektóre z nich, częściej jednak tylko poszczególne fragmenty albo pojedyncze wyrazy, wyróżnione zostały przez zastosowanie powiększonej czcionki lub wythuszczenia druku. Ze względu na powtarzające się tematy rozmieszczono je w taki sposób, aby zachowana została równowaga, o czym redaktor tomu pisze: „u potrazi za simetrijom osmislio sam algoritam po kojem su raspoređena sjećanja. Na taj način postigao sam ravnotežu najprisutnijih emocija i najčešćih tema" [s. 25]. Poddając analizie zebrane wspomnienia, zauważyć można, że nierzadko powtarzają się w nich te same słowa. Do najczęstszych należą między innymi granata lub granatiranje, podrum, mrak, voda, glad, hrana i hladnoća. Opisują one przestrzeń, w której rozgrywały się wydarzenia, oraz warunki egzystencji uwięzionych w mieście mieszkańców. Wiele wspomnień wiąże się też ze śmiercią bliskich osób, najczęściej rodziców, rodzeństwa lub przyjaciół. W jednym z nich czytamy: „Kada sam dobio Mars čokoladicu i Pepsi limenku, shvatio sam da mi je otac poginuo. Ahmed, 1984" [s. 116]. Wpisów tego typu jest bardzo wiele. O śmierci najczęściej mówi się wprost, językiem nieskomplikowanym i dosadnym, bez zbędnych metafor.

W świetle zgromadzonych relacji wybuch konfliktu wyznacza kres pewnego etapu życia. Dzieciństwo i wojna stały się dla wielu uczestników projektu niemoż- 
liwe do pogodzenia. Pierwsze z pojęć przedstawiane jest zawsze jako okres bezpieczeństwa, beztroski i szczęśliwości, który został gwałtownie przerwany i bezpowrotnie utracony. We wspomnieniach wielokrotnie pojawiają się podobne sformułowania: „stracić”, „odebrać” czy „ukraść”. Wojna zaś utożsamiana jest najczęściej z katastrofą i piekłem, o którym jej uczestnicy nie chcą pamiętać, jednak, mimo usilnych starań, nie mogą o nich zapomnieć.

Nema djetinjstva u ratu... To je ono što izgubiš čim naučiš da prepoznaš svaki kalibar granate i snajpera. Dalida 1980. [s. 37]

Izgubljeno djetinjstvo. Prebrzo odrastanje da bih mogla shvatiti šta su granate i geleri. Safa, 1983. [s. 194]

Oduzeli su mi najbolje godine, jedan dio mene - onaj veseli, najljepši, zauvijek izgubljen... Dino, 1976. [s. 169]

Nisam ni shvatio da sam dijete, odjednom sam postao zreli momak bez lijepih sjećanja. Djetinjstvo su nam ukrali. Minja, 1982. [s. 167]

Ništa ... ama baš ništa. To nije djetinjstvo, već mučenje... Nikad se nikome ne ponovilo!. Semir, 1988. [s. 193]

Biti dijete u ratu znači nemati djetinjstvo! Selma, 1983 [s. 61]

Nisam imala djetinjstvo te 4 godine i u meni još uvijek čuči djevojčica željna tih godina da ih podijeli s lutkicama. Dina 1982. [s. 200]

To nije bilo djetinjstvo. To je bio pakao... Haris, 1985. [s. 207]

Moje djetinjstvo je bježanje od stvarnosti: ja nisam imala djetinjstvo. Ines, 1988. [s. 129]

Najgora moguća stvar koja se može desiti jednom djetetu. Dragana, 1985. [s. 71] [s. 204]

Djetinjstvo kojeg se ne želimo sjećati, a ipak je urezano u naše pamćenje. Amela, 1986.

Djetinjstvo u ratu je zauvijek ubilo dijete u meni. Dženana, 1985. [s. 149]

Djetinstvo u ratu je za mene velika trauma u miru! Amir, 1979. [s. 141]

Przeciwwagą dla tego typu sformułowań są wspomnienia, w których pojawia się zupełnie odmienny obraz dzieciństwa. Dla omawianego tu zbioru znamienne jest to, że mimo okropieństw wojny, które na wiele miesięcy stały się dla tysięcy sarajewian codziennością, wiele osób starało się cieszyć życiem. W ich wspomnieniach smutek łączy się z radością, a śmiech ze łzami.

Užas s jedne strane, a s druge dosta lijepih trenutaka koje sam provela sa svojim prijateljima. Selma, 1981. [s. 59]

Izgubljene, ali istovremeno i nezaboravne godine. Damir, 1975. [s. 53]

Prašnjavo sklonište, mrak, strah... Al' život je lijep kao dječji smijeh. Elma, 1983. [s. 99]

Tuga i smijeh. Tuga zbog rata i protjerivanja iz doma, smijeh zbog malih velikih dječijih radosti. Kanan, 1987. [s. 112]

To je melodija dječijih osmijeha pomiješanih sa zvucima projektila iznad naših glava... Namik, 1988. [s. 123]

Uzeli su nam slobodu... Ali nam nikad nisu mogli uzeti osmijeh s naših dječjih lica. Lejla, 1981. [s. 149]

Tuga i radost upakovane zajedno. Hana, 1984. [s. 170] Smijeh, tuga i strah. Merima, 1989. [s. 186]

Suze i smijeh ,zrelog djeteta”. Alma, 1978. [s. 187]

Brzo odrastanje i super druženje kakvog danas nema. Oliver, 1982. [s. 207]

Najužasniji period sreće iz najužasnijeg mjesta sreće na svijetu. Mladen, 1985. [s. 107] 
To je djetinjstvo u prahu... hahaha, mlijeko u prahu, jaja u prahu, kuće oko nas u prahu... ali smo mi bili veseli! Zlata, 1984. [s. 109]

Przez wielu mieszkańców oblężenie rodzinnego miasta zostało zapamiętane przede wszystkim jako czas zabawy oraz wielkich przyjaźni, które przetrwały próbę czasu. We wspomnieniach niejednokrotnie akcentowana jest ludzka solidarność, gotowość do pomocy, troska, empatia oraz wzajemne wsparcie, których obecnie w relacjach międzysąsiedzkich często brakuje. Przyjaźń ukazana została jako największa wartość, która potrafi sprawić, że życie staje się lepsze i piękniejsze.

Ja sam jedno od ranjene djece iz rata. Bilo je teško, ali drugarstvo je bilo bolje nego danas! Arijana, 1980. [s. 44]

Zvuči čudno, ali pamtim ga po lijepom: sijela u podrumima, zezancija, igra djece u haustoru, druženje sa starijom rajom... Irfan, 1986. [s. 59]

Jedno veliko iskustvo u kojem smo svi bili jednaki i više privrženi drugima. Šefika, 1976. [s. 62]

Period u životu kada sam upoznao svoje iskrene prijatelje... to su i danas ljudi koji me razumiju. Vahidin, 1980. [s. 68]

Bili smo sretniji u ratu. Nismo imali ništa (struje, vode, hrane...), ali smo bili bliže jedni drugima. Admir, 1982. [s. 81]

Svi smo bili isti... ljudi su bili bliski. Bezbroj prijateljstva u tako tužnom okruženju. Igor, 1976. [s. 86]

Neponovljivi trenuci sa dragim osobama, komšijama, prijateljima... Sanela, 1977. [s. 89]

Niti jedna granata nije mogla da promijeni sjećanja koja imam na djetinjstvo. I u onom paklu bilo je sretno. Nejra, 1986. [s. 203]

Stekla sam najbolje prijatelje na svijetu, odrasla sam prije vremena, ali ne žalim ni za jednom minutom. Marina, 1981. [s. 145]

Velika ironija je to što su bez obzira na rat i teška vremena to bili najljepši dani mog djetinjstva i života. Alma, 1987. [s. 132]

Czytając przytoczone wspomnienia, zauważyć można, że ich autorzy często wypowiadają się w liczbie mnogiej i używają zaimka osobowego „my”, podkreślając $\mathrm{w}$ ten sposób istnienie pewnej wspólnoty, dla której dzieciństwo przypadające na okres wojny w Bośni i Hercegowinie oraz oblężenia jej stolicy stało się czynnikiem pokoleniotwórczym. W pracach zajmujących się problemem pokoleniowości, zwłaszcza w tych fundamentalnych, autorstwa Kazimierza Wyki czy Jana Garewicza, akcentuje się fakt, że przeżycie generacyjne zazwyczaj wiąże się z wydarzeniami o charakterze przełomowym dla dziejów świata i ludzkości, najczęściej wojnami czy przewrotami. Wyka podkreśla, że „głównym elementem konstytutywnym pokolenia jest swoiste przeżycie czasu - czas usiany zdarzeniami i stosunek do tego czasu" 6 . Z kolei Garewicz pisze, że „zdarzenie pokoleniowe jest inicjacją" , ,pierwszym zbiorowym spotkaniem ze złem, a tym samym także z dobrem" ${ }^{8}$. W ujęciu badaczy z przeżyciem pokoleniowym nieodzownie łączy się ka-

${ }^{6}$ K. Wyka, Pokolenia literackie, Kraków 1989, s. 53.

7 J. Garewicz, Pokolenie jako kategoria socjo-filozoficzna, [w:] Na krawędzi epoki. Rozwój duchowy i działanie człowieka, red. J. Rudniański, K. Murawski, Warszawa 1985, s. 141.

8 Ibidem, s. 148. 
tegoria młodości, kiedy to dochodzi do kształtowania się więzi między członkami danej generacji, oraz wyjątkowość i niepowtarzalność ich doświadczeń. Wyka wielokrotnie pisze o „wybranych rocznikach”. Wtóruje mu Garewicz, podkreślając, że: „Przynależność do pokolenia przytrafia się tylko nielicznym”" ${ }^{10}$. Wojenne dzieciństwo stało się zatem dla całego pokolenia sarajewian doświadczeniem o charakterze generacyjnym, które wyróżnia tę wspólnotę, będąc, bez względu na przynależność narodowościową jej członków, fundamentem ich tożsamości oraz poczucia wyjątkowości, czego potwierdzenie odnajdujemy w słowach Jasminka Halilovicia:

Razgovori s Ivanom podsjetili su me na prve poslijeratne godine, kad smo se u školi počeli dijeliti na one koji su bili tu i one koji nisu bili tu. Oni koji nisu bili tu bili su (najčešće prešutno, ali gotovo redovno) u određenoj mjeri odbačeni od društva. Kao da smo mi, koji smo bili tu, tražili način da ih kaznimo. [s. 29]

Podczas lektury uwagę zwraca jeszcze jeden fakt. W relacjach często pojawia się informacja, że autorzy sami już są rodzicami i chcieliby przekazać pamięć o traumatycznych wydarzeniach, które stały się częścią ich biografii, kolejnemu pokoleniu. Jeden z uczestników projektu pisze: „Danas, kad se sjetim, pamtim samo najdivnije trenutke... sve loše sam potisnuo u neku svoju riznicu, da je jednom otvorim djeci... Edin, 1983". [s. 163] Pod wieloma aspektami świadectwa te odbiegają od innych wspomnień i relacji z lat konfliktu w Bośni i Hercegowinie. Różnią się przede wszystkim perspektywą czasową. Wojenne wydarzenia nie są relacjonowane na bieżąco, ale wydobywane z pamięci. Wydawać by się mogło, że autorzy powrócili już z wojennego exodusu do normalnego życia, dorośli i założyli rodziny. Jednak presja tragicznych wydarzeń okazała się tak silna, że, mimo wielu lat od zakończenie konfliktu, odczuli — można powiedzieć — przymus spisania swoich wspomnień i przekazania ich innym, kolejnemu pokoleniu. Ochrona pamięci oraz przekazanie jej dzieciom stała się dla przedstawicieli generacji wojennej swoistego rodzaju obowiązkiem. Paul Ricoeur moment ten określa mianem archiwum. „Pierwotnie świadectwo ma charakter ustny — jest słyszane, wysłuchiwane. Archiwum to pismo - odczytuje się je, trzeba do niego sięgnąć"11 — podkreśla badacz i dodaje: „świadectwo można za sprawą pisma przyjmować, deponować"12.

Zbiór Djetinjstvo u ratu jest tego typu archiwum, miejscem chroniącym ślady i pamiątki dokumentalne, miejscem, w którym zostały zebrane, są przechowywane i klasyfikowane ${ }^{13}$. Dla archiwum znamienny jest moment przelania wspomnień na papier, utrwalenia w formie graficznej śladów odciśniętych w pamięci. „W tym sensie - jak podkreśla francuski filozof — pojęcie archiwum przywraca gestowi pisania całe bogactwo" 14 , a „zmiana statusu świadectwa mówionego na archiwalne

\footnotetext{
9 Zob. K. Wyka, Pokolenia..., s. 74.

10 J. Garewicz, Pokolenie jako..., s. 140.

11 P. Ricoeur, Pamięć, historia, zapomnienie, przeł. J. Margański, Kraków 2007, s. 220.

12 Ibidem, s. 221.

13 Zob. ibidem.

14 Ibidem, s. 222-223.
} 
stanowi pierwszą historyczną przemianę w żywej pamięci"15. Dokumenty archiwalne nie mają określonego adresata, w przeciwieństwie do świadectw ustnych nie są skierowane do konkretnych odbiorców, słuchaczy. Ponadto wspomnienia sarajewian w procesie archiwizacji doznały swego rodzaju nobilitacji. Archiwum bowiem — jak podkreśla Ricoeur — „stanowi autorytet dla tego, kto doń sięga"16.

Fundamentem archiwum są teksty. Jednakże w przypadku doświadczeń wojennego pokolenia sarajewian pozostało również bardzo wiele niepisanych świadectw dziecięcej gehenny. Te szczątki przeszłości, niemi świadkowie, są najczęściej „ulubionymi obiektami archeologii”" ${ }^{17}$. Z nimi między innymi wiąże się drugi projekt zainicjonowany przez Jasminka Halilovicia — Muzej ratnog djetinjstva. To jedno z najnowszych przedsięwzięć, którego celem jest komemoracja wojennego losu miasta i jego mieszkańców. Bolesne doświadczenie stało się po zakończeniu konfliktu w Bośni i Hercegowinie fundamentem, na którym budowany jest wizerunek współczesnego Sarajewa jako miejsca naznaczonego piętnem urbicydu ${ }^{18}$. Doświadczenie wojny domaga się jednak usankcjonowanych instytucji i miejsc pamięci, gdyż — jak podkreśla Magdalena Bogusławska — „coraz częściej staje się wątkiem wykorzystywanym w lokalnej ofercie turystycznej ${ }^{19},[\ldots]$ ukierunkowuje politykę kulturalną miasta, wpływa również na jego kulturową ekonomię"20. Pomysł utworzenia Muzeum Wojennego Dzieciństwa zasadza się na tej samej co w wypadku omawianego wcześniej zbioru wspomnień potrzebie werba-

15 Ibidem, s. 223.

16 Ibidem, s. 224.

17 Ibidem, s. 226.

18 Pamięć o tragicznej przeszłości wyraża się przede wszystkim przez muzea i wystawy, pomniki, nazwy mostów i ulic, budynki do dziś noszące ślady artyleryjskich ataków, „sarajewskie róże”, nazywane wcześniej ,śladami smoczej łapy” — oznaczające miejsca po wybuchach pocisków, w których zginęli ludzie, oraz liczne cmentarze.

19 Działająca w stolicy Bośni i Hercegowiny organizacja turystyczna Sarajevo Discovery Center w swojej ofercie ma wycieczki nawiązujące tematycznie do oblężenia Sarajewa. Podczas jednej z nich, opatrzonej nazwą „Times of Misfortune” i określanej przez organizatorów mianem „flagowej”, zobaczyć można wiele zachowanych śladów wojennej przeszłości miasta. Jej program obejmuje między innymi: wizytę na placu targowym Markale, gdzie w dwóch masakrach (5 lutego 1994, 28 sierpnia 1995) zginęło łącznie niemal stu sarajewian, a blisko trzystu zostało rannych; spacer po mieście śladami „sarajewskich róż”; przejażdżkę po słynnej Alei Snajperów (Bulevar Meše Selimovića); wizytę w muzeum utworzonym w miejscu dawnego tunelu pod lotniskiem (Tunel Spasa. Spomenički kompleks) oraz spacer na jeden z sarajewskich cmentarzy. Do niedawna w ofercie biura była również wycieczka pod tytułem „Mission Impossible Tour”, podczas której turyści mieli okazję odwiedzić miejsca, w których rozlokowani byli snajperzy, oraz zniszczone obiekty sportowe będące areną rywalizacji podczas XIV Zimowych Igrzysk Olimpijskich. Organizatorzy podkreślają, że przewodnikami wycieczkowiczów są osoby, które przeżyły — najczęściej jako dzieci — oblężenie miasta, starając się tym samym zaakcentować prywatny i osobisty wymiar wojennego doświadczenia. Obszernie na ten temat zob. http://sarajevodiscovery.com/package/times-of-misfortune/ [dostęp: 13.08.2019] Zob. też M. Skrzeszewska, „Kap moje krvi poteče i Bosna ne presuši” - pamięć o oblężeniu Sarajewa, „Studenckie Zeszyty Naukowe UJ” 2014, nr 2 (6).

${ }^{20}$ M. Bogusławska, Nowe formy instytucjonalizacji pamięci na Batkanach i w Polsce (komparatystyczne studium trzech przypadków), „Balcanica Posnaniensia” 2017, nr 24, s. 162-163. 
lizacji przeżyć przez pokolenie, które we wczesnych latach życia doświadczyło ogromnego cierpienia. Jego założyciel podkreśla, że podczas prac nad pierwszym projektem jego uczestnicy zaczęli nadsyłać różnego rodzaju pamiątki, które dały początek muzeum ${ }^{21}$. Mottem przedsięwzięcia uczyniono hasło: „Umuzeji svoje uspomene!"22. Umuzealnienia może dokonać każdy, kto jako dziecko przeżył wojnę w Bośni i Hercegowinie. Wystarczy wypełnić zamieszczony na stronie internetowej placówki formularz obejmujący siedem punktów — oprócz danych osobowych i kontaktowych należy wskazać miejsce zamieszkania w okresie wojny oraz sposób uczestnictwa w tworzeniu muzeum. W przedsięwzięciu można wziąć udział, nadsyłając pamiątki i/lub nagrywając film-świadectwo ${ }^{23}$.

Muzej ratnog djetinjstva nie prezentuje wojny w sposób podręcznikowy, akcentujący chronologię wydarzeń. Ekspozycja opiera się na uwiecznionych w formie wideo wspomnieniach prywatnych osób, które skonfrontowane zostały z rekwizytami stanowiącymi materialną reprezentację opowieści. Zgromadzone przedmioty trudno jednak uznać za typowe pamiątki wojenne. Odnajdujemy tu zabawki, gry planszowe, książki, zeszyty z zapiskami, opakowania po produktach spożywczych czy przedmioty codziennego użytku. Eksponaty nierzadko stanowiły dla osób uczestniczących w przedsięwzięciu impuls do rozpoczęcia wojennej opowieści. Są katalizatorami pracy pamięci i modelują obraz przeszłości ${ }^{24}$.

Muzej ratnog djetinjstva to nie tylko przestrzeń ekspozycyjna, lecz także archiwum. Paul Ricoeur podkreśla, że „zasadniczy rdzeń archiwum tworzą teksty" ${ }^{25}$. W tym przypadku ich funkcję pełnią nagrania typu oral history. Formuła muzeum zaś nawiązuje do narracyjności rozumianej jako jeden ze sposobów doświadczania rzeczywistości oraz konstruowania pamięci.

Narracyjność — podkreśla francuski badacz — nie stanowiąc bynajmniej przeszkody dla naukowego charakteru historii, staje się jej substytutem. Ta szkoła myślenia, stając w obliczu skrajnych wymogów reprezentowanych przez nomologiczny model poznania historycznego, przystąpiła do ponownego oszacowania możliwości rozumienia, jakie daje opowieść ${ }^{26}$.

W podobnym tonie wypowiadają się inni badacze, wśród nich Hayden White, dostrzegając $\mathrm{w}$ narracji podstawową formę ujmowania rzeczywistości, porządkowania i wyjaśniania świata oraz nadawania mu sensu ${ }^{27}$. Dzięki formule narratorium sarajewskie muzeum nie tylko ukazuje, co i przez kogo zostało zapamiętane z tego bolesnego okresu, lecz także w jaki sposób, co zdaniem Bogusławskiej nadaje mu wartość metamuzeum ${ }^{28}$.

${ }^{21}$ Więcej na ten temat zob. https://www.tvn24.pl/wiadomosci-ze-swiata,2/w-sarajewie-powstaje-pierwsze-muzeum-dziecinstwa-czasu-wojny,666074.html [dostęp: 13.08.2019].

$22 \mathrm{https}: / /$ djetinjstvouratu.com/muzej/umuzeji-svoje-uspomene/ [dostęp: 13.08.2019].

23 Zob. ibidem.

24 Zob. M. Bogusławska, Nowe formy instytucjonalizacji..., s. 164.

25 P. Ricoeur, Pamięć, historia..., s. 223.

26 Ibidem, s. 321.

27 Zob. H. White, Poetyka pisarstwa historycznego, red. E. Domańska, M. Wilczyński, Kraków 2010, s. 22.

28 Zob. M. Bogusławska, Nowe formy instytucjonalizacji..., s. 164.

Slavica Wratislaviensia 173, 2020

(C) for this edition by CNS 
Reasumując, podkreślić pragnę, że zarówno książka Djetinjstvo u ratu, jak i Muzej ratnog djetinjstva prezentują odpolitycznioną i odheroizowaną wizję wojny. Ich pomysłodawca nie miał na celu stworzenia całościowego obrazu wydarzeń. Obydwa projekty, będące odpowiedzią na konkretne zapotrzebowanie społeczne, akcentują to, co jednostkowe i indywidualne, angażując przy tym emocje czytelnika, widza i słuchacza. Muzeum, w mniejszym stopniu książka, której placówka jest naturalną kontynuacją, tworzą kolekcje otwarte. Każdy z przedstawicieli pokolenia wojennego może je dopełnić własnymi wspomnieniami i pamiątkami ${ }^{29}$. Uczestnicy obydwu projektów wyszli ze swoimi opowieściami w przestrzeń publiczną, inicjując przepływ między jednostką a społeczeństwem. W ten sposób pamięć o oblężeniu Sarajewa i cierpieniach mieszkających w nim dzieci stają się ostrzeżeniem dla ludzkości. Djetinjstvo u ratu, jak też Muzej ratnog djetinjstva są miejscami spajającymi całe pokolenie, bez nich głos tej zbiorowości byłby niesłyszalny, a trwanie grupy niemożliwe. Dla wielu jego członków są formą terapii, o czym Amina Krvavac, dyrektor wykonawczy muzeum, mówi: „Iz osobne perspektive, mogu reći da mi je bilo važno da izađem iz statusa žrtve, da ne budem samo dijete koje je imalo djetinjstvo u ratu, nego i da možemo nešto pozitivno napraviti s tim iskustvom, da iz toga izađemo osnaženi"30.

Obydwa projekty służą również przekształceniu pamięci pokoleniowej w pamięć odziedziczoną, pamięć potomków generacji, która przeżyła zbiorową traumę. Podjęte przez pomysłodawców zabiegi komemoracyjne mają na celu nie tyle zapoznanie czy oswojenie z doświadczeniami ojców, ile sprawiają, że doświadczenia te wrastają z taką siłą w świadomość pokolenia dzieci, że są odczuwane jako własne, tworzą „fundament ich własnej pamięci”"31. Wspomniana Amina Krvavac w jednym z wywiadów podkreśla: „drago mi je kad vidim da i drugi doživljavaju muzej kao svoj. Ova djeca iz ulice tu su svaki dan, rade domaće zadaće ovdje, znaju sve eksponate" 32 . Wspomnienia oraz eksponaty tworzą całość, którą za Marianne Hirsch można określić mianem ,wizualnej przestrzeni postpamięci” (visual space of postmemory $)^{33}$. Obydwa projekty służą zbudowaniu międzypokoleniowej, ho-

${ }^{29}$ Ekspozycja nie ma charakteru stałego, a artefakty eksponowane są w sposób rotacyjny. W zasobach muzeum znajduje się około 4 tysięcy eksponatów, a w przestrzeni galeryjnej prezentowanych jest zaledwie około 50. Co ważne, zbiór systematycznie się powiększa.

$30 \mathrm{https} / /$ www.jutarnji.hr/vijesti/svijet/jasminko-halilovic-upravo-je-izabran-na-forbesovulistu-30-ispod-30-listu-koja-okuplja-najutjecajnije-ljude-na-svijetu-mlade-od-trideset-godina/6977436/ [dostęp: 13.08.2019].

31 M. Hirsch, Pokolenie postpamięci, przeł. M. Borowski, M. Sugiera, „Didaskalia” 2011, nr 105, s. 29.

32 https://www.jutarnji.hr/vijesti/svijet/jasminko-halilovic-upravo-je-izabran-na-forbesovulistu-30-ispod-30-listu-koja-okuplja-najutjecajnije-ljude-na-svijetu-mlade-od-trideset-godina/6977436/ [dostęp: 13.08.2019].

33 M. Hirsch, Projected memory: Holocaust photographs in personal and public fantasy, [w:] Acts of Memory. Cultural Recall in the Present, red. M. Bal, J. Crewe, L. Spitzer, London-Hanover 1999, s. 7. Wizualnemu dyskursowi postpamięci poświęcone są też inne prace badaczki. Zob. eadem, Family frames. Fotography, Narrative and Postmemory, Cambridge-Massachusetts-London 1997; 
ryzontalnej postpamięci afiliacyjnej ${ }^{34}$, która „stanowi efekt życia w tym samym czasie oraz związku z konkretnym drugim pokoleniem w połączeniu ze strukturami zapośredniczenia, które powszechnie można sobie przyswoić, gdyż są na tyle łatwo dostępne i pojemne, że zasięgiem organicznej sieci transferu obejmują większą zbiorowość" 35 . Dzięki temu osoby pośrednio związane z przeszłością stają się częścią pokolenia postpamięci, która przetrwa nawet wówczas, gdy odejdą wszyscy świadkowie i uczestnicy wydarzeń. Omówione tu formy pamięci tak mocno oddziałują, gdyż przeszłość powraca — jak pisze Hirsch — „w postaci inwestycji wyobrażeń, różnego rodzaju projekcji czy twórczości artystycznej”36.

\section{Bibliografia}

Bogusławska M., Nowe formy instytucjonalizacji pamięci na Bałkanach i w Polsce (komparatystyczne studium trzech przypadków), „Balcanica Posnaniensia” 2017, nr 24.

Garewicz J., Pokolenie jako kategoria socjo-filozoficzna, [w:] Na krawędzi epoki. Rozwój duchowy $i$ działanie człowieka, red. J. Rudniański, K. Murawski, Państwowy Instytut Wydawniczy, Warszawa 1985.

Halilović J., Djetinjstvo u ratu. Sarajevo 1992-1995., Udruženje Urban, Sarajevo 2012.

Hirsch M., Family frames. Fotography, Narrative and Postmemory, Harvard University Press, Cambridge, MA-London 1997.

Hirsch M., Pokolenie postpamięci, przeł. M. Borowski, M. Sugiera, „Didaskalia” 2011, nr 105.

Hirsch M., Projected memory: Holocaust photographs in personal and public fantasy, [w:] Acts of Memory. Cultural Recall in the Present, red. M. Bal, J. Crewe, L. Spitzer, University Press of New England, London-Hanover 1999.

Hirsch M., Surviving images: Holocaust photographs and the work of postmemory, [w:] Visual Culture and the Holocaust, red. B. Zelizer, Rutgers University Press, New Brunswick-New Jersey 2001.

Ricoeur P., Pamięć, historia, zapomnienie, przeł. J. Margański, Universitas, Kraków 2007.

Skrzeszewska M., „Kap moje krvi poteče i Bosna ne presuši” — pamięć o oblężeniu Sarajewa, „Studenckie Zeszyty Naukowe UJ” 2014, nr 2 (6).

White H., Poetyka pisarstwa historycznego, red. E. Domańska, M. Wilczyński, Universitas, Kraków 2010.

Wyka K., Pokolenia literackie, Wydawnictwo Literackie, Kraków 1989.

http://sarajevodiscovery.com/package/times-of-misfortune/.

https:/djetinjstvouratu.com/muzej/umuzeji-svoje-uspomene/.

https://www.jutarnji.hr/vijesti/svijet/jasminko-halilovic-upravo-je-izabran-na-forbesovu-listu30-ispod-30-listu-koja-okuplja-najutjecajnije-ljude-na-svijetu-mlade-od-trideset-godina/6977436/.

https://www.tvn24.pl/wiadomosci-ze-swiata,2/w-sarajewie-powstaje-pierwsze-muzeumdziecinstwa-czasu-wojny,666074.html.

eadem, Surviving images: Holocaust photographs and the work of postmemory, [w:] Visual Culture and the Holocaust, red. B. Zelizer, New Brunswick-New Jersey 2001.

${ }^{34}$ Hirsch dokonała rozróżnienia na dwa typy postpamięci — afiliacyjną oraz przekazywaną $\mathrm{w}$ ramach rodziny postpamięć rodzinną (familial postmemory). Szerzej na ten temat zob. eadem, Pokolenie..., s. 31-32.

35 Ibidem.

36 Ibidem, s. 29.

Slavica Wratislaviensia 173, 2020

(C) for this edition by CNS 


\section{Archiving and Musealisation of Generational Memory. War Childhood by Jasminko Halilović and War Childhood Museum}

\section{Summary}

The work focused on the archiving and musealisation process of the collective memory of the youngest residents of the war in Sarajevo. The paper discusses two projects initiated by Jasminko Halilovic - a collection of memories entitled War Childhood and War Childhood Museum - whose purpose is to commemorate the war destiny of the city and its inhabitants. Referring among others to the theoretical findings made by Paul Ricoeur and research on post-memory, to works by Marianne Hirsch in particular, I show that childhood during the war has become a generational factor. Protection of memory and passing it on to children became a kind of duty for representatives of this generation. Both projects are also used to transform generational memory into post-memory, an inherited memory that will survive even when all witnesses and participants of the war events are gone.

Keywords: siege of Sarajevo, War Childhood, War Childhood Museum, memory archiving, memory musealisation, generation, post-memory

\section{Arhiviranje i muzealizacija generacijske memorije. Jasminko Halilović Djetinjstvo u ratu. Sarajevo 1992-1995. i Muzej ratnog djetinjstva}

Sažetak

Rad je fokusiran na proces arhiviranja i muzealizacije kolektivnog pamćenja najmlađih stanovnika ratnog Sarajeva. Rad istražuje dva projekta koje je pokrenuo Jasminko Halilović - zbirku sjećanja pod nazivom Djetinjstvo u ratu. Sarajevo 1992-1995. i Muzej ratnog djetinjstva - čija je svrha komemoracija ratne sudbine grada i njegovih stanovnika. Pozivajući se, između ostalog, na teorijske koncepte Paula Ricoeura i istraživanja posvećena postmemoriji, posebno djela Marianne Hirsch, pokazujem da je ratno djetinjstvo postalo generacijski faktor. Zaštita pamćenja i prenošenje sjećanja na djecu postale su svojevrsna dužnost za predstavnike ove generacije. Rad donosi zaključak da istraživani projekti doprinose transformiranju generacijske memorije u postmemoriju (naslijeđeno sjećanje) koja će preživjeti čak i kad svi svjedoci i sudionici ratnih događaja će nestati.

Ključne riječi: opsada Sarajeva, Djetinjstvo u ratu. Sarajevo 1992-1995., Muzej ratnog djetinjstva, arhiviranje sjećanja, muzealizacija sjećanja, generacija, postmemorija 